\title{
Exploring entrepreneurial culture and its socio-cultural determinants: in case of Woldia University graduating students
}

\author{
Abriham Ebabu Engidaw
}

\author{
Correspondence: Abreshman0921@ \\ gmail.com \\ Management Department, Woldia \\ University, Woldia, Ethiopia
}

\begin{abstract}
The purpose of this study was to explore entrepreneurial intention and its determinants: in the case of Woldia University graduating students. To achieve its objectives, the study employed a descriptive and explanatory research design, and in the study, a cross-sectional study was conducted through a mixed research approach. The target population of the study was 223 regular first-degree 2018 graduating students of Woldia University, Management Department, and their instructors in the study area. The sample size was 143 respondents. The study result showed that majority of the respondents did not plan to start their own knowledgebased business. This was essentially due to the lack of competence in transforming ideas in to practice and commercializing it to create their own business.

Correspondingly, prodigious attention should be given to have an entrepreneurial orientation in the contents and methods of teaching at all levels of education systems primary, secondary, and higher educational institutions and use different awareness-raising mechanisms in the country.
\end{abstract}

Keywords: Entrepreneurial culture, Determinants of entrepreneurship, Employment

\section{Introduction}

Entrepreneurship is described as the function of handling economic activity, undertaking risk, creating something new, and organizing and coordinating resources for innovating new ideas, products and services (Gupta and Srinivasan 1999: 1.17). And also, entrepreneurial culture refers to the total sum of dynamic and innovative ways and the means by which entrepreneurs respond to changes in the environment (Lucky 2011: 220). Being $20 \%$, unemployment is the most persistent and urgent development challenge for African countries (Economic Commission for Africa 2009: 17).

In developing regions like Africa, it has been argued that the better-educated people experience higher unemployment rates. In Africa, for educated people, entrepreneurship is a necessity rather than an opportunity. They established their own business because finding wage employment is highly competitive and full of corruption. They are forced to start a business and become self-employed (Schaumburg-Müller et al. 2010: 4). In Ethiopia, 50\% of the population in the age group between 15 and 30 years

(c) The Author(s). 2021 Open Access This article is licensed under a Creative Commons Attribution 4.0 International License, which permits use, sharing, adaptation, distribution and reproduction in any medium or format, as long as you give appropriate credit to the original author(s) and the source, provide a link to the Creative Commons licence, and indicate if changes were made. The images or other third party material in this article are included in the article's Creative Commons licence, unless indicated otherwise in a credit line to the material. If material is not included in the article's Creative Commons licence and your intended use is not permitted by statutory regulation or exceeds the permitted use, you will need to obtain permission directly from the copyright holder. To view a copy of this licence, visit http://creativecommons.org/licenses/by/4.0/. 
old is unemployed (Eshetu and Mammo 2009: 2), and this figure is among the highest unemployment rates worldwide. Any endeavor to understand the entrepreneurial spirit among people should include an examination of the socio-economic origins of the entrepreneurs (Gupta and Srinivasan 1999: 1.7).

So far, researches mostly focus on the entrepreneurial culture determinants that people faced with starting a business. Temesgen (2020) found that entrepreneurship education course has a significant effect on students' entrepreneurial intention that increases knowledge, skills, and confidence of the students to become entrepreneurs. Katz's (1992) study result shows that family expectations and background influence entrepreneurial cultures of students. Similarly, Peterman and Kennedy (2003) found that the intention to start a new business becomes more positive by prior family exposure to entrepreneurship. However, the findings of Abebe and Angriawan (2011: 2) indicate more than $50 \%$ youth in Ethiopia are unemployed and the problem still persists in the country. According to Abebe and Angriawan (2011: 2), self-employment is less among the young, the educated, and those who migrated to urban areas recently. Megibaru (2012) in his empirical study confirmed that the need for independence and opportunity-seeking behaviors of students who have taken an entrepreneurship course are higher than those of students who did not.

However, there are few studies conducted on the socio-cultural basis of entrepreneurship, entrepreneurial culture/intention, and the effects of the socio-cultural conditions of graduating students on the development of entrepreneurial culture and entrepreneurship. Hence, this study investigated the variation of entrepreneurial culture among 2018 graduating university students in the case area. It also explored and examined the socio-cultural environment of those graduating students with the aim of identifying the courage and constraint factors for the development of entrepreneurial culture among those students.

This study would contribute to fill the practical and knowledge gap in the socio-cultural dimensions of entrepreneurship. It provides an insight for policy makers with regard to the socio-cultural courage and constraints of entrepreneurial development in Ethiopia especially with those prospective innovative human powers of the country, graduating university students. It would provide a platform for action to mainstream entrepreneurship in education and other forms of socialization. It would also support entrepreneurial advocators by providing empirical evidence about the nature and socio-cultural and policy constraints of entrepreneurial development in the country.

\section{Study objectives}

1. To investigate the effect of residential area of respondents on entrepreneurial culture

2. To analyze the effect of work expectation of respondents' family on entrepreneurial culture

3. To examine the effect of status of respondents in taking on entrepreneurship course on entrepreneurial culture (EC)

4. To investigate the effect of community attitude of respondents on entrepreneurial culture 


\section{Literature review}

\section{Entrepreneurship}

Entrepreneurship needs an entrepreneurial culture which refers to the ability of people to be more creative, innovative, highly motivated, self-confident, willing to challenge, better communicators, decision-makers, leaders, negotiators, problem solvers, team players, systematic thinkers, less dependent, less risk averse, able to live with uncertainty, and capable of recognizing opportunities. Entrepreneurial qualities are difficult to indoctrinate in the new generation within a short period of time. In our country, unemployment is the most persistent and urgent development challenge. Surprisingly, the better-educated people experience higher unemployment rate. Entrepreneurship is considered as a second work career while people are unable to enroll in large organizations.

Developing a business plan is also another quality of an entrepreneur by which the entrepreneurs will make profit by creating value for its customers, shareholders, partners, and other connected entities. Family background, education, previous work experience, risk attitude, over-optimism, preference for independence, and the norm and values of a society influence the choice of individuals' life careers, i.e., entrepreneurship or salaried employment (Sanditov and Verspagen 2011: 2). Parents encourage or discourage them from entering certain life careers. Parental influences also make a significant difference in individuals' life chances both through the material advantages and psycho-social support of their respective family. Generally, all agents of socialization in the home and in the society have their own part in inculcating individuals with the life ways of the society. In addition to its role in evaluating life careers, culture also enables to suggest or judge which kinds of work are appropriate and inappropriate for different groups. Formal educational institutions serve as a socializing agent alongside the general cultural and family socialization processes (Watson 2008: 233).

Subsequently, entrepreneurial culture is the backbone for entrepreneurship development, dealing with those factors affecting the entrepreneurial culture of the young generation especially the educated part of the society, and is a critical step in promoting entrepreneurial thinking and engagement of those parts of the society in such adaptive mechanisms.

\section{Entrepreneurial culture}

Samli (2009: 56) characterized successful entrepreneurs as being creative thinkers and strongly aware of their environment to know and choose appropriate opportunities that lead to success. They are able to identify opportunities in improving the existing system. They have to understand and evaluate the opportunity options in their surroundings. The European Commission (2008: 26) also argued the character qualities of an entrepreneur as more creative, innovative, highly motivated, self-aware, selfconfident, willing to challenge, better communicators, decision-makers, leaders, negotiators, networkers, problem solvers, team players, systematic thinkers, less dependent, less risk averse, able to live with uncertainty, and capable of recognizing opportunities.

Entrepreneurship needs entrepreneurial culture that implies a set of values, norms, and traits that is conducive to the growth of entrepreneurship (Gupta and Srinivasan 1999: 1). Entrepreneurial culture is an individual's ability to transform ideas into action and enables young people to be more creative and self-confident in whatever they undertake (European Commission 2008: 18). 
Theoretical reviews on determinants of entrepreneurial culture

Residential area of respondents

Based on different studies, students of urban and rural residents had almost similar entrepreneurial qualities. However, students of urban residents were higher in personal control than students of rural residents. Relatively, students of urban background more likely plan to be entrepreneurs than those of rural background.

As De Hoyos-Ruperto (2009) stated, the probability of being self-employed affected with residential and cultural backgrounds of students that shape the attitudes toward risk, which in turn influence the choice to become an entrepreneur. Based on his empirical evidence, Maphosa (1998) concluded that residential and social factors have an effect on the development of entrepreneurship/entrepreneurial culture. And they also stated the courage or impeding effect of residential factors on the students' entrepreneurial culture. Farrington et al. (2012) analyzed the possessing of certain demographic attributes of individuals who exhibit entrepreneurial intents than those who do not. The sample comprised of undergraduate business students from three South African Universities. A statistical analysis was undertaken, and a chi-square statistics was calculated to decide the significant relationships between the demographic attributes and entrepreneurial goals. The results showed that the residential and demographic variables of university attended, level of study, and ethnicity had a significant impact on the intentions of respondents to begin their own businesses.

The above theoretical and empirical reviews lead to the following hypothesis:

Hypothesis 1: Residential area of respondents has a significant effect on students' plan to be an entrepreneur in the study area.

\section{Work expectation of respondents' family}

In Maphosa (1998), MacLelland argued that the development of entrepreneurial characteristics was related to parental treatment. High achievers were those who had been expected and encouraged by their parents to be capable of self-reliant and independent action at an early age. Perceptions of autonomy are affected by interactions with significant others such as peers, friends, and family whose attitudes can either frustrate or support autonomy (Kamaumaina 2006: 15). As Maphosa (1998: 175) stated, by encouraging behaviors that is associated with self-reliance, risk-taking, innovation, and individualism, parents or other relatives help their children develop an entrepreneurial personality. The influence of the family in the development of an entrepreneurial personality is stronger where there is family tradition of business. A business family, particularly the father and mother, encourage behaviors associated with entrepreneurship.

Most often children are affected with the work choice of their own parents.

Based on the finding of Nanda and Sorensen (2009), family and friends have a great influence on individual's/student's career choice because they are considered as fund providers and role models. It is found in the literature that the role of friends and role models is prominent in influencing the decisions to become an entrepreneur. The above discussion and reviews lead to the following hypothesis:

Hypothesis 2: Work expectation of respondents' family have a significant effect on entrepreneurial culture in the study area. 


\section{Status of respondents in taking entrepreneurship course}

Among essential stakeholders, academic institutions take a lion share in shaping the attitudes, skills, and entrepreneurial behaviors of people (World Economic Forum 2009: 15). Education at all levels plays in developing entrepreneurial attitudes, skills, and behaviors and in building innovation capabilities. This includes building selfconfidence, self-efficacy, and leadership skills, particularly at the primary and secondary levels (United Nations 2010). Entrepreneurship education can help promote an entrepreneurial and innovative culture by changing mindsets and providing the necessary skills (World Economic Forum 2009: 15).

As per Varga (2000), university graduates may be one of the most important channels for disseminating knowledge from academia to the local high-technology industry. Analyzing patent citations, Jaffe et al. (1993) found that knowledge spillovers from academic research to private industries have a strong regional component for the importance of proximity for the use of public science. Without a doubt, we believe that universities ought to take steps to encourage entrepreneurial movement in their environments. Therefore, the dual role of the modern academic mission now requires universities not only to serve society by educating students but also to foster research that can be developed into commercially viable products and technologies (Kirby 2006). A low level of education and exposure could prevent motivated entrepreneurial movement in their surroundings. Research evidence by Clark (1998) has shown that they are in relation with the concept of universities' attempts to reform them and to become more entrepreneurial by strengthening their steering core, enhancing the development periphery, widening the funding base, stimulating the academic heartland, and promoting an entrepreneurial belief. Saxenian (1994) points out that one of the important mechanisms facilitating knowledge spillovers involves the mobility of human capital, embodied in graduating students as they move from the university to a firm. This could be perceived as an institutional characteristic - an institution aiming to foster enterprising individuals (Gibb 2006) and to change and take risks (Barnett 2005), its faculties and staff operating as academic entrepreneurs within the university and capable of innovating and sustaining technology transfer beyond it (Shattock 2005). Generally, many empirical evidences shows that the educational system of entrepreneurship courses creates awareness of alternative business choices to graduating students and broadens the horizon of individuals, enabling them to perceive and develop entrepreneurial opportunities.

The study result of Israr and Saleem (2018) portrays that entrepreneurial education had a positive effect on students' entrepreneurial intentions as one unit increased in entrepreneurial education; intentions to become an entrepreneur increased by 0.09 units. Megibaru's (2012) empirical study confirmed that the need for independence and opportunity-seeking behaviors of students who have taken entrepreneurship course are higher than those of students who did not. And also based on Davey et al.'s (2011) and Jones' (2011) findings, entrepreneurial education increases entrepreneurship intentions and raises the knowledge and skills of individuals as well. Entrepreneurship intention can be influenced to address various subjective norms and resources which are barriers to create new ventures. It has been shown that positive relationship occurs between economics and business education and business creation. Also, the above argument and reviews lead to the following hypothesis:

Hypothesis 3: Status of respondents in taking entrepreneurship course has a significant effect on entrepreneurial culture. 


\section{Community attitude}

Positive approaches of the surrounding community concerning entrepreneurship are likely to upturn one's desire to engage in entrepreneurial activities, and more specifically, individuals who experience a positive view on entrepreneurship among their immediate contacts are more likely to have greater intention to become entrepreneurs. For instance, it is often recognized that among people of Chinese origin, entrepreneurial role models encourage people to go into business supported by close networks of family members and relatives (Kao 1993; Siu and Martin, 1992).

Based on his empirical evidence, Maphosa (1998: 175) concluded that community attitude/social factors have an encouraging or impeding effect on the development of entrepreneurship. Cultural attitude is also one of the mechanisms that contribute to entrepreneurial success, and it would positively be related to a motivating force for business growth. In the Czech and Slovak Republics, negative public attitudes toward entrepreneurs disheartened entrepreneurs (Swanson and Webster 1992). Another study of Mokry (1988) proposed that local communities can play an important role in developing an entrepreneurial environment. Based on the above discussion, the hypothesis below is developed:

Hypothesis 4: Community attitude of respondents has a significant effect on entrepreneurial culture.

Hence, the drawbacks of previous studies are that they are limited on some variables only and failed to see the relationship among these dependent and independent variables on different organization perspectives.

\section{Conceptual framework}

Based on the above theoretical and empirical reviews, the following conceptual framework was developed by the researcher (Fig. 1).

\section{Regression model specification}

$$
Y=\mathrm{B} 0+\beta 1 \mathrm{X} 1+\beta 2 \mathrm{X} 2+\beta 1 \mathrm{X} 3+\beta 2 \mathrm{X} 4+\mathrm{e}
$$

where $Y=$ entrepreneurial culture

$\mathrm{X} 1=$ residential area of respondents

$\mathrm{X} 2$ = work expectation of respondents' family

$\mathrm{X} 3$ = status of respondents in taking entrepreneurship course

$\mathrm{X} 4=$ community attitude of respondents

$\beta=$ Beta coefficient

$\mathrm{B} 0=$ constant

$e=$ other factors not included in the study (0.05 random error)

\section{The current study}

The study was aimed at exploring entrepreneurial culture and its socio-cultural determinants: in the case of graduating university students. Based on the overall findings of the study, the general conclusions and recommendations are drawn. 


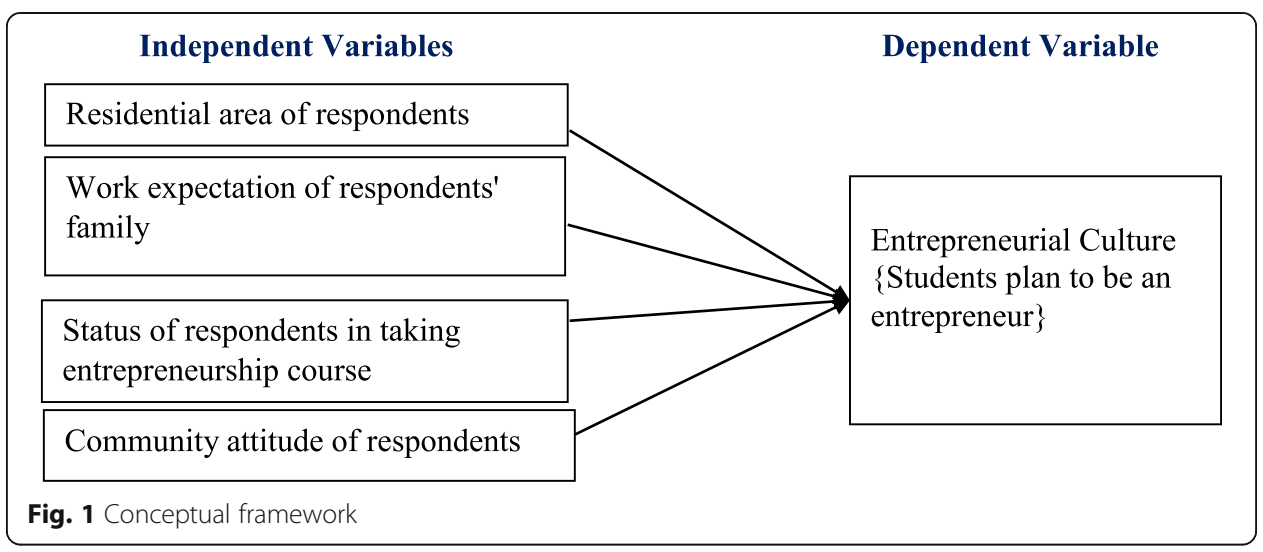

\section{Methodologies}

This study used descriptive and explanatory research designs, and it employed a mixed research approach. The quantitative part of this research was employed to provide a statistical generalization about the variation of entrepreneurial cultures among graduating university students with different socio-cultural exposure and look at the effects of different socio-cultural variables of those students on their entrepreneurial knowledge, attitudes, and skills, and future work choice. And also, a qualitative research approach was used to provide detailed descriptions of the social settings in which graduating students spent their life time including their exposure in the university. It was also employed to provide a detailed explanation about the relationship among dependent and independent variables. Furthermore, a detailed investigation was conducted to explain why variation in entrepreneurial cultures happened among those students who are living with different socio-cultural conditions. The population of this study was the regular first-degree Management Department 2018 graduating students and their instructors. However, the total number of regular first-degree graduating management students of the university was 223 , so the sample size was calculated using the following Yamane's sample size determination formula:

$$
\left(n=\frac{N}{\left(1+N e^{2}\right)}\right) \text { were } 143
$$

In this study, the estimate of confidence level (95\%) within 5\% degree of accuracy has been used. For the quantitative parts of this study, respondents were selected based on stratified sampling techniques by using their section as a stratum. Stratified and systematic sampling techniques were used to minimize the chance of selecting respondents from the same socio-cultural background including their educational background. For interview, purposive sampling technique was employed in order to incorporate teachers and students who were knowledgeable to the socio-cultural environmental conditions. One male and one female class representatives from each five sections were selected and participated in the focus group discussions. Two discussion sessions were held with 10 participants in each group. And also, the collected data was analyzed through correlation and multiple linear regression analysis. 


\section{Study materials \\ Measures of variables}

To explore the relationship between dependent and independent variables, the data were gathered through standardized and self-administered questionnaires conducted among regular first-degree graduating students of 2018 in this university. This instrument was used to examine the variation of entrepreneurial culture among graduating students in the university and to look at the effects of different socio-cultural variables on the development of entrepreneurial culture among those students. Questionnaires were adapted from entrepreneurial concepts and theories formulated by previous researchers in the area and the researcher. Standardized questionnaires, Entrepreneurial Attitude Orientation (EAO) used with some modifications, and also the data collection instruments were arranged in the English language.

\section{Results}

\section{Scale reliability}

The reliability was statistically tested by using the most commonly used statistics Cronbach alpha coefficient, and all seven scales had a high level of reliability. Prior to conducting the main study, a pilot test was conducted using 25 graduating students at the university to check the feasibility of the questionnaires. The reliability test confirmed the internal consistency in responses, and it indicated that the measures were reliable and acceptable enough.

\section{Response rate}

In this study, the sample size was 143 . The researcher distributed 143 questionnaires, and all respondents volunteered to give their responses for the questionnaire and appropriately completed and returned because the respondents were convenient to the researcher. That makes the process simple. So, the response rate was $100 \%$. This was an adequate and statistically acceptable response rate.

\section{Correlational results}

In order to determine whether there are significant relationships among the independent variables and the dependent variable, the Pearson correlation coefficient analysis had been carried out, as shown in Table 1. According to Cohen (1992), an interpretation of the range of the coefficient of correlation has been described as follows: -0.3 to +0.3 weak, 0.5 to -0.3 or 0.3 to 0.5 moderate, -0.5 to -0.9 or 0.5 to 0.9 strong, and -0.9 to -1 or 0.9 to 1 very strong.

In the above table, Pearson product moment correlation analysis result shows that there was a strong positive significant relationship between the independent variable work expectation of respondents' family and the dependent variable entrepreneurial culture at correlation coefficient and sig. level of 0.604 (.000), and also, the status of respondents in taking entrepreneurship course has a positive relationship with entrepreneurial culture at correlation coefficient and sig. level of 0.683 (.000). On the one hand, there was a strong positive significant relationship between community attitude of respondents and the dependent variable entrepreneurial culture (plan to be an entrepreneur) at correlation coefficient and sig. level of 0.683 (.000). On the other 
Table 1 Correlation statistics

\begin{tabular}{|c|c|c|c|c|c|c|}
\hline & & $\begin{array}{l}\text { Residential } \\
\text { area }\end{array}$ & $\begin{array}{l}\text { Work } \\
\text { exp. of } \\
\text { family }\end{array}$ & $\begin{array}{l}\text { Status of } \\
\text { course } \\
\text { take }\end{array}$ & $\begin{array}{l}\text { Community } \\
\text { attitude }\end{array}$ & $\begin{array}{l}\text { Entrepreneurial } \\
\text { culture }\end{array}$ \\
\hline \multirow[t]{3}{*}{$\begin{array}{l}\text { Residential area } \\
\text { of respondents }\end{array}$} & $\begin{array}{l}\text { Pearson } \\
\text { correlation }\end{array}$ & 1 & .117 & -.024 & .123 & -.004 \\
\hline & Sig. (two-tailed) & & .162 & .772 & .143 & .962 \\
\hline & $N$ & 143 & 143 & 143 & 143 & 143 \\
\hline \multirow[t]{3}{*}{$\begin{array}{l}\text { Work expectation of } \\
\text { respondents' family }\end{array}$} & $\begin{array}{l}\text { Pearson } \\
\text { correlation }\end{array}$ & .117 & 1 & .560 & .563 & .604 \\
\hline & Sig. (two-tailed) & .162 & & .000 & .000 & .000 \\
\hline & $N$ & 143 & 143 & 143 & 143 & 143 \\
\hline \multirow{3}{*}{$\begin{array}{l}\text { Status of respondents } \\
\text { in taking entrepreneurship } \\
\text { course }\end{array}$} & $\begin{array}{l}\text { Pearson } \\
\text { correlation }\end{array}$ & -.024 & .560 & 1 & .638 & .683 \\
\hline & Sig. (two-tailed) & .772 & .000 & & .000 & .000 \\
\hline & $N$ & 143 & 143 & 143 & 143 & 143 \\
\hline \multirow[t]{3}{*}{ Community attitude } & $\begin{array}{l}\text { Pearson } \\
\text { Correlation }\end{array}$ & .123 & .563 & .638 & 1 & .683 \\
\hline & Sig. (two-tailed) & .143 & .000 & .000 & & .000 \\
\hline & $N$ & 143 & 143 & 143 & 143 & 143 \\
\hline \multirow{3}{*}{$\begin{array}{l}\text { Entrepreneurial culture } \\
\text { (plan to be an } \\
\text { entrepreneur) }\end{array}$} & $\begin{array}{l}\text { Pearson } \\
\text { correlation }\end{array}$ & -.004 & .604 & .683 & .683 & 1 \\
\hline & Sig. (two-tailed) & .962 & .000 & .000 & .000 & \\
\hline & $N$ & 143 & 143 & 143 & 143 & 143 \\
\hline
\end{tabular}

hand, the residential area of respondents has no significant relationship with the dependent variable at correlation coefficient -0.004 and sig. level of $0.962(P>0.05)$.

The overall result of correlation, histogram, and p-p plot (Additional file 1) showed that there was no problem of multi co-linearity, normality, and linearity in the study variables.

\section{Regression analysis (Table 2)}

Based on the above Table 2 result, the value of $R$ square is 0.622 and the adjusted $R$ square is 0.605 . This implied that $62.2 \%$ of variation in entrepreneurial culture is explained by socio-cultural determinants in the study area. And also, the significance value of $\mathrm{F}$ statistics indicates a value .000 , and it was less than $p<0.05$, meaning that the model was significant enough and there is no model fitness problem on this study (Table 3).

The regression analysis result proves that work expectation of respondents' family have a positive significant effect on students' entrepreneurial culture at standardized beta value of 0.208 at $p=0.005$, status of respondents in taking entrepreneurship course have a positive significant effect on students' entrepreneurial culture at standardized beta value of 0.286 at $p=0.000$, and also community attitude of respondents have a positive significant effect on students' entrepreneurial culture at standardized beta value of 0.306 with significance level of 0.000 . This clearly shows that community attitude of respondents was the most contributing factor for the students' entrepreneurial culture in this study area. Contrarily, residential area of respondents have not a significant effect on the dependent variable at sig. level of $.0181(p>0.05)$ in the study area. 
Table 2 Regression analysis

\begin{tabular}{|c|c|c|c|c|c|c|c|c|c|}
\hline \multicolumn{10}{|c|}{ Model summary } \\
\hline \multirow[t]{2}{*}{ Model } & \multirow[t]{2}{*}{$R$} & \multirow[t]{2}{*}{$R$ square } & \multirow{2}{*}{$\begin{array}{l}\text { Adjusted } \\
R \text { square }\end{array}$} & \multirow{2}{*}{$\begin{array}{l}\text { Std. error } \\
\text { of the } \\
\text { estimate }\end{array}$} & \multicolumn{5}{|c|}{ Change statistics } \\
\hline & & & & & $\begin{array}{l}R \text { square } \\
\text { change }\end{array}$ & F change & df1 & df2 & Sig. F change \\
\hline 1 & $.789^{a}$ & .622 & .605 & .42508 & .622 & 37.283 & 6 & 136 & .000 \\
\hline
\end{tabular}

${ }^{\mathrm{a}}$ Predictors: constant, residential area, community attitude, work expectation of family, and status of respondents in taking entrepreneurship course

Source: Own survey, 2018

\section{Model equation}

Based on the above regression analysis, result regression model equation seems like the following:

$$
Y=0.695+(0) \mathrm{X} 1+(0.208) \mathrm{X} 2+(0.286) \mathrm{X} 3+(0.306) \mathrm{X} 4+\mathrm{e}
$$

where $Y=$ entrepreneurial culture

$\mathrm{X} 1$ = residential area of respondents

$\mathrm{X} 2$ = work expectation of respondents' family

$\mathrm{X} 3$ = status of respondents in taking entrepreneurship course

$\mathrm{X} 4=$ community attitude of respondents

$e=$ other factors not included in the study ( 0.05 random error)

\section{Discussions}

In our country, Ethiopia, young graduating university students are less likely to prefer to be an entrepreneur. In this study, the mean score value of independent variables work expectation of respondents' family, status of respondents in taking entrepreneurship course, and community attitude of respondents is 3.1427, 3.0503, and 2.9343, respectively; this is approaching to low. The dependent variable entrepreneurial culture mean score value indicated 3.0839 which is a moderate value. From the total of 143 respondents, majority of respondents did not plan to start their own knowledge-based business. Based on instructors' and those students' response, this was mainly due to lack of competence in transforming ideas (theories) in to practice and commercializing it to create their own business and lacking startup money.

Based on the focus group discussion result, open-ended questions, and interview results, taking an entrepreneurship course contributes a lot in inculcating students with entrepreneurial qualities. The focus group discussion method helped to have rich and

Table 3 Regression coefficients

\begin{tabular}{|c|c|c|c|c|c|c|}
\hline \multicolumn{2}{|c|}{ Model } & \multicolumn{2}{|c|}{$\begin{array}{l}\text { Unstandardized } \\
\text { coefficients }\end{array}$} & \multirow{2}{*}{$\begin{array}{l}\text { Standardized } \\
\text { coefficients } \\
\text { Beta }\end{array}$} & \multirow[t]{2}{*}{$t$} & \multirow[t]{2}{*}{ Sig. } \\
\hline & & B & Std. error & & & \\
\hline \multirow[t]{5}{*}{1} & Constant & .695 & .294 & & 2.361 & .020 \\
\hline & Residential area of respondents & -.070 & .052 & -.073 & -1.345 & .181 \\
\hline & Work expectation of respondents' family & .208 & .073 & .197 & 2.860 & .005 \\
\hline & $\begin{array}{l}\text { Status of respondents in taking } \\
\text { entrepreneurship course }\end{array}$ & .286 & .074 & .289 & 3.868 & .000 \\
\hline & Community attitude of respondents & .306 & .065 & .346 & 4.738 & .000 \\
\hline
\end{tabular}

Dependent variable: entrepreneurial culture Source: Own survey, 2018 
synthesized information about why and how entrepreneurial thinking developed in some groups of students and why not in others. This method was employed to grasp detailed information about the socio-cultural exposures of those students. As per majority of discussants, the less entrepreneurial intention of students is mainly due to lack of competence for transforming theories in to practice and commercialization of knowledge in the world market. The families for majority of graduating students desired to see their children as an employee in large non-governmental or governmental organizations. As some discussants stated, the surrounding community, especially the rural areas, might perceive that students failed in the academic world if they prefer to be an entrepreneur, as soon as graduation.

The Pearson product moment correlation analysis result proves the strong positive significant relationship between the independent variables status of respondents in taking entrepreneurship course, work expectation of respondents' family, and community attitude of respondents and the dependent variable entrepreneurial culture. On the other hand, the residential area of respondents has no a significant relation with the dependent variable.

Based on the assumption test result of correlation, histogram, and p-p plot which is shown in Additional file 1, there was no problem of multi co-linearity, normality, and linearity in the study variables, because, as indicated in the co-linearity statistics, the tolerance values of all predicator variables were greater than 0.01 which is under the acceptable standard. So, the relationship between predictor and independent variables was very less. Additionally, there is no outlier on the p-p plot and scatter plots.

The $R$ square value is 0.622 and the adjusted $R$ square is 0.605 ; this implied that $62.2 \%$ of variation in entrepreneurial culture is explained by socio-cultural determinants in the study area, and the rest $37.8 \%$ of variation entrepreneurial culture is affected by other variables not included in this study. The two-way ANOVA test result showed that there is no model fitness problem on this study.

Also, the regression analysis result verifies that, firstly, the residential area of respondents has no significant effect on the dependent variable at sig. level of $.0181(p>0.05)$ in the study area. This result contradicted with the previous studies of Peterman and Kennedy (2003), Katz (1992), Nanda and Sorensen (2009), Maphosa (1998), and Farrington et al. (2012).

Hypothesis 1: Residential area of respondent has a significant effect on students' plan to be an entrepreneur in the study area. The decision rule is to reject the alternative hypothesis and accept the null hypothesis.

Secondly, the status of respondents in taking entrepreneurship course has a positive significant effect on students' entrepreneurial culture at $B=0.286, P=000.0$.

This finding supports the previous study results of Temesgen (2020), Megibaru (2012), Davey et al. (2011), Jones (2011), and Israr and Saleem (2018) because their empirical study confirmed that entrepreneurial education had a positive effect on students' entrepreneurial culture and the need for independence and opportunity-seeking behaviors of students who have taken entrepreneurship course are higher than those of students who did not.

Hypothesis 2: Work expectation of respondents' family have a significant effect entrepreneurial culture in the study area. So, the decision is to accept the alternative hypothesis and reject the null hypothesis. 
Thirdly, work expectation of respondents' family has a positive significant effect on students' entrepreneurial culture. These results, thus, support the evidence of the previous studies (Nanda and Sorensen 2009; Shapero 1984; Scott and Twomey 1988.

Hypothesis 3: Status of respondents in taking entrepreneurship course has a significant effect on entrepreneurial culture. The decision rule is to accept the alternative hypothesis and reject the null hypothesis

Lastly, community attitude of respondents have a positive significant effect on students' entrepreneurial culture, and the study clearly shows that the community attitude of respondents was the most contributing factor for the students' entrepreneurial culture in this study area. This is because, in societies like Ethiopia, individuals are not free to decide on their own affairs and activities, life ways, and work career choices which highly depend on the decision of their family group, peer group, the values and judgment given by the local community, and different factors. This finding supports the study results of Maphosa (1998: 175), Swanson and Webster (1992) and Mokry (1988).

Hypothesis 4: Community attitude of respondents has a significant effect on entrepreneurial culture. So, the decision is to accept the alternative hypothesis and reject the null hypothesis

In general, students whose role model/s is/are self-employed in the business sector had higher achievement motivation, need for innovation, opportunity-seeking behaviors, personal control and risk-taking behavior, need for independence, and self-esteem than those who did not have. Family work expectation had a statistically significant influence on the intentions of students towards entrepreneurship as their future work career. Students who planned to be an entrepreneur were those who had been expected and encouraged by their parents to be capable of self-reliance and independence. Students whose family's future work career expectation is employment in huge institutions or organizations were less likely plan to start and run their own business than those whose family desired entrepreneurship as a future work career of their children soon after graduation.

\section{Recommendations and conclusions}

Based on this empirical study result, the researcher forwarded the relevant recommendations and conclusions below:

The study indicates that socio-cultural factors like work expectation of respondents' family, status of respondents in taking entrepreneurship course, and community attitude of respondents have a positive significant effect on students' entrepreneurial culture, and the study clearly shows that community attitude of respondents was the most contributing factor for the students' entrepreneurial culture. Decision on life careers of individuals are highly affected with the perception of the family and the society at large. In fact, in the collaboration of higher educational institutions with real practitioners, entrepreneurship should be enhanced to mitigate the limitations of higher educational instructors (highly specialized in the theoretical aspects of the academics but less in practical experience with the real working environment and in adapting/ transforming theories into practice in order to exploit the resource potentials of the country). This university should also try to solve students' attitude problems about entrepreneurship by making different decisions including developing education policies 
that support the development of entrepreneurial culture and needed in building such collaboration with other successful model organizations. To indoctrinate the graduate students with good entrepreneurial capabilities, policy makers at all stages of the society and the Ministry of Education should design entrepreneurial supportive policies, strategies, and resource allocations for the sector.

Moreover, social media and other socializing institutions should invite and give enormous time coverage for entrepreneurial role models to share their practical experiences to motivate new entrepreneurs and create awareness to the whole community. Also, additional research should be conducted to explore the real factors that affect students' entrepreneurial culture in different area.

\section{Conclusions}

The main objective of this study was to explore entrepreneurial culture and its sociocultural determinants: in the case of the university's Management Department graduating students. In the study, various parameters are used, namely, independent variables (residential area of respondents, work expectation of respondents' family, status of respondents in taking entrepreneurship course and community attitude of respondents) and dependent variable (entrepreneurial culture). To achieve the research objectives, the statistical relationship of each independent variable with the dependent variable was well examined and presented in the study in line with the study questions using regression and correlational analyses. Afterwards, in examining all the parameters entirely, the researcher found that the status of respondents in taking entrepreneurship course, work expectation of respondents' family, and community attitude of respondents have a positive significant effect on students' entrepreneurial culture, and the study clearly shows that the community attitude of respondents was the most contributing factor for the students' entrepreneurial culture in this study area.

\section{Suggestion for future study}

It is obvious that entrepreneurial culture will be affected by different socio-cultural, geographical, demographic, and other related factors in the world. So, future researchers should investigate more research to test the variation of entrepreneurial culture and its determinants among different graduating university students and even under the whole community. Based on the study findings, socio-cultural factors included in this research are explaining only $62.2 \%$ variation on students' entrepreneurial culture but the rest $37.8 \%$ will be affected by the other variables which were not included in this study and left for further study.

\section{Abbreviations}

EAO: Entrepreneurial Attitude Orientation; EC: Entrepreneurial Culture

\section{Supplementary Information}

The online version contains supplementary material available at https://doi.org/10.1186/s13731-021-00155-7.

Additional file 1. Charts. 


\section{Author's contributions}

The study was independently conceived by AEE was the only author for this article. The author(s) read and approved the final manuscript.

\section{Funding}

No funding information, but eligible for waiver opportunities on Springer Journals.

\section{Availability of data and materials}

All the meta data used under the current study are available from the corresponding author on reasonable request.

\section{Declaration}

Competing interests

The author declares that there are no competing interests.

Received: 9 September 2020 Accepted: 7 March 2021

Published online: 09 April 2021

\section{References}

Abebe, M. A., \& Angriawan, A. (2011). The internationalisation of small and medium-sized enterprises (SMEs): A multi-level integrative framework. International Journal of Entrepreneurship and Innovation Management, 13(3-4), 377-397.

Barnett, R. (2005). Convergence in higher education: The strange case of "entrepreneurialism". Higher Education Management and Policy, 17(3), 51-64 African Economies, Oxford University. (MSMEs) for Sustainable Rural Livelihood. Working Paper No. 11. Aalborg.

Clark, B. R. (1998). Creating entrepreneurial universities: Organizational pathways to transformation. Pergamon Press. CEPR Cohen, J. (1992) Statistical Power Analysis. Current Directions in Psychological Science, 1(3), 98-101.

Davey, T., Plewa, C. and Struwig, M., (2011) Entrepreneurship perceptions and career intentions of international students. Education + Training, 53(5), 335-352.

De Hoyos-Ruperto, M. (2009). Toward an understanding for entrepreneurship environment: the case of Puerto Rico (Doctoral dissertation, CASE WESTERN RESERVE UNIVERSITY). https://www.researchgate.net/publication/266497633

Economic Commission for Africa. (2009). Expanding opportunities for and with young people in Africa: African Youth Report.

Eshetu Bekele \& Mammo Muchie. (2009). Promoting micro, small and medium enterprises (MSMEs) for sustainable rural livelihood (DIIPER Research Series, Working Paper No. 11). Aalborg University.

European Commission, (2008). Communication from the Commission to the Council, the European Parliament, the European Economic, and Social Committee and the Committee of the Regions of 25 June 2008 entitled "Think Small First" - A "Small Business Act" for Europe (COM - 2008 - 394 final). European Commission, Brussels.

Farrington, S. M., et al. (2012). Entrepreneurial intentions: Demographic perspectives of South African business students. South African Journal of Business Management, 43(3), 41-49.

Gibb, A. (2006). Towards the entrepreneurial university. Entrepreneurship education as a lever for change. International Journal of Entrepreneurship Education, 4(1), 73-110.

Gupta, B. C., \& Srinivasan, P. N. (1999). Entrepreneurial development, (6th ed., ).

Jaffe, A., Trajtenberg, M., \& Henderson, R. (1993). Geographic localization of knowledge spillovers as evidenced by patent citations. Quarterly Journal of Economics, 63, 577-598.

Jones, C. (2011). Teaching Entrepreneurship to Undergraduates. Cheltenham: Edward Elgar Publishing.

Kamaumaina, R. (2006). Stimulating youth entrepreneurship in Kenya. Retrieved July 8, 2019 from http://weatherhead.case edu/edm/archieve/files/concept/Maina\%20-Concept\%20Paper\%206-21-06.pdf.

Kao, J. (1993). The worldwide web of Chinese business. Harvard Business Review, 71(2), 24-36.

Katz, J. (1992). A psychological cognitive model of employment status choice. Entrepreneurship Theory \& Practice, 17(1), 29-37.

Kirby, D. A. (2006). Creating entrepreneurial universities in the UK: Applying entrepreneurship theory to practice. The Journal of Technology Transfer, 31(5), 599-603.

Lucky, E. O. (2011). Nurturing entrepreneurship development in the 21 st century: the practical approaches. International Journal of Humanities and Social Science, 1(9), 219-227.

Maphosa, F. (1998). Towards the sociology of Zimbabwean indigenous entrepreneurship. Zambezia, 25(2), 173-190.

Israr, M., \& Saleem, M. (2018). Entrepreneurial intentions among university students in Italy. Journal of Global Entrepreneurship Research, 8(1), 1-14.

Megibaru, S (2012) Socio-Demographic Determinants for Entrepreneurial Intention of University Students: The Case of University of Gondar Graduating Students. Ethiopian Journal of Business and Economics 4 (1):50

Mokry, B. W. (1988). Entrepreneurship and public policy: Can government stimulate business startups? Quorum Books.

Muhammad, I., \& Mazhar, S. (2018). Entrepreneurial intentions among university students in Italy. Journal of Global Entrepreneurship Research, 8(1), 1-14.

Nanda, R.. \& Sorensen, J. (2009). Workplace Peers and Entrepreneurship (March 10, 2009). Harvard Business School Entrepreneurial Management (No. 08-051). Working Paper.

Peterman, N. E., \& Kennedy, J. (2003). Enterprise education: Influencing students' perceptions of entrepreneurship. Entrepreneurship theory and practice, 28(2), 129-144.

Samli, A. C. (2009). International entrepreneurship: innovative solutions for a fragile planet. University of North Florida. Sanditov, B. \& Verspagen, B. (2011). Multilevel analysis of the determinants of innovative entrepreneurship across Europe.

Saxenian, A. (1994). Regional advantage: culture and competition in Silicon Valley and RTE. Harvard University Press.

Schaumburg-Müller, H., Jeppesen, S., \& Langevang, T. (2010). Entrepreneurship development in Africa. In Report from a workshop. Working Paper Series.

Scott, M., \& Twomey, D. (1988). The long-term supply of entrepreneurs: student's career aspirations in relation to entrepreneurship. Journal of Small Business Management, 26(4), 5-13. 
Shapero, A. (1984). The entrepreneurial event. In C. A. Kent (Ed.), The environment for entrepreneurship. Lexington, Mass: Lexington Books.

Shattock, M. (2005). European universities for entrepreneurship: Their role in the Europe of knowledge. Higher Education Management and Policy, 17(3), 13-25.

Siu, W. S., \& Martin, R. G. (1992). Successful entrepreneurship in Hong Kong. Long Range Planning, 25(6), 87-93.

Swanson, D., \& Webster, L. (1992). Private sector manufacturing in Czech and Slovak Federal Republic: a survey of firms (Industry and Energy Department Working Paper, Industry Series Working Paper No. 68).

Temesgen, (2020) Socio-demographic determinants of entrepreneurial intention in case of University graduating students

United Nations. (2010). Entrepreneurship education, innovation and capacity-building in developing countries. http://www. unctad.org/en/docs/ciimem1d9_en.pdf

Varga, A. (2000). Local academic knowledge transfers and the concentration of economic activity. Journal of Regional Science, 40(2), 289-309.

Watson, T. J. (2008). Sociology, work and industry, (5th ed.).). MPG Books Group.

World Economic Forum (2009). World Economic Forum Annual Meeting. http://www.feelingeurope.eu/Pages/WEF\%202 009\%200peningSpeechKlausSchwab.pdf.

\section{Publisher's Note}

Springer Nature remains neutral with regard to jurisdictional claims in published maps and institutional affiliations.

Submit your manuscript to a SpringerOpen ${ }^{\circ}$ journal and benefit from:

- Convenient online submission

- Rigorous peer review

- Open access: articles freely available online

- High visibility within the field

- Retaining the copyright to your article

Submit your next manuscript at $\boldsymbol{\nabla}$ springeropen.com 